\title{
TAX COUNTS: BRINGING MONEY-LAW TO LATCRIT
}

\author{
Alice G. Abreu* \\ I. INTRODUCTION
}

Tax and business law have generally remained outside the LatCrit enterprise, and that is too bad. The problem may be that tax and business law seem to be ultimately about money, and worrying about money appears so crass-so alien to the issues of anti-subordination and social justice that have occupied center stage in LatCrit discourse. Those of us who labor in areas of the law concerned with the distribution, protection and multiplication of money might therefore seem unlikely contributors to the LatCrit enterprise. LatCrit $V$ changed that.

LatCrit $\mathrm{V}$ was unique because it began the process of integrating the money areas of the law ("money-law") ${ }^{1}$ into the LatCrit enterprise. Despite the usual absence of these areas from critical discourse, at LatCrit $\mathrm{V}$, we learned that activists and scholars have been putting money-law knowledge to work in creative ways which advance the LatCrit agenda. We learned, for example, of a new and different approach to legal aid, one that focused on providing the legal aid needed to start businesses within immigrant communities in Miami. ${ }^{2}$ We also learned of the connection between tax and Indian law. ${ }^{3}$

* Professor of Law, Temple University School of Law, Philadelphia, PA 19122. I am indebted to Frank Valdes and Lisa Iglesias, who invited me to present an early version of this essay at LatCrit $V$ and who have listened and acted upon much of what I have urged, and to my friend Berta Esperanza Hernandez Truyol, who has always provided support and inspiration. The LatCrit enterprise continues to benefit from their energy, insight and wisdom. Temple Law School provided generous financial support for my attendance at LatCrit $\mathrm{V}$ and for the writing of this essay, and for that, I am grateful. As always, the views expressed here are mine alone, as are all errors.

1. By "money-law," I mean the areas traditionally viewed as comprising the business curriculum: tax, corporations, securities, commercial law (UCC), securities, banking, antitrust and the like.

2. Russell Jacobs spoke of his work with Steps Toward Success, a legal aid program that goes beyond solving particular problems or disputes to help low-income individuals develop the skills and resources necessary for long-term business success. The program relies on entrepreneurship to provide an exit from poverty, apparently taking its cue from the Chinese proverb: "Give a [person] a fish, and you feed [her] for a day. Teach a [person] to fish, and you feed [her] for a lifetime." RHODA THOMAS TRIPP, THE INTERNATIONAL THESAURUS OF QUOTATIONS 981 (1970).

3. Scott Taylor, of the University of New Mexico, spoke about the ways that tax law intersects with Indian law and affects the status and well-being of Native Americans, a subject to which he has devoted recent scholarship. See Scott A. Taylor, State Property Taxation of Tribal Fee Lands Located Within Reservation Boundaries: Reconsidering County of Yakima v. Confederated Tribes and Bands of the Yakima Indian Nation and Leech Lake Band of Chippewa Indians v. Cass 
This essay grows out of my participation in LatCrit $\mathrm{V}$ and explores a number of connections between three seemingly disparate subjects: the Cuban Revolution, LatCrit scholarship and contemporary tax policy. As a tax lawyer, teacher, and scholar, I have devoted much of my professional life to the study of a system that might seem to be only about money. As I will try to demonstrate, however, the system is actually about much more. It reflects our views about who should win and who should lose, and why. ${ }^{4}$

Although money-law is often seen as involving what Fidel Castro dubbed preocupaciones burgesas, ${ }^{5}$ of import only to those who have money and thus have reason to care about its protection and multiplication, such a view is shortsighted. A study of the ways in which the law entrenches the distribution of money and enhances its multiplication should be within the purview of all scholars who care about antisubordination, because the law can entrench and abet the absence of money and thus contribute to continued subordination. As I will demonstrate, tax systems can do precisely that.

This essay, which draws on the narrative piece I wrote following LatCrit III as well as on my experience as a speaker and participant in LatCrit V, explores the ways in which those of us who work in moneylaw can enhance the LatCrit project. ${ }^{6}$ Although I have centered my discussion on tax because that is the area I know best, I hope that my comments prompt other business law scholars to share insights grounded in their areas of expertise. My aim is to prompt those who believe in the anti-subordination objective of LatCrit to work to bring more Latina/os into these areas of the law so that these areas do not remain a fiefdom of the Anglo majority. LatCrit V began that process-I want to foster its growth.

\section{MONEY, THE SECOND GENERATION}

My claim is that the concern about money and economic well-being is not just a preocupacion burgesa but is, at bottom, a concern about human rights. Social, economic and cultural rights may be referred to as

County, 23 AM. INDIAN L. Rev. 55, 56 (1998); and Scott A. Taylor, An Introduction and Overview of Taxation and Indian Gaming, 29 ARIZ. ST. L.J. 251, 251 (1997).

4. See generally Martin J. McMahon, Jr. \& Alice G. Abreu, Winner-Take-All Markets: Easing the Case for Progressive Taxation, 4 FLA. TAX REV. 1 (1998).

5. The phrase translates almost literally as bourgeois concerns. Fidel Castro often used this phrase during the early days of the Cuban Revolution as a way of expressing contempt for what he considered the petty worries of the affluent.

6. See Alice G. Abreu, Lessons From LatCrit: Insiders and Outsiders, All at the Same Time, 53 U. MIAMI L. REV. 787 (1999). 
second-generation human rights,' but the important thing is that they are acknowledged to be human rights. ${ }^{8}$ After five years, LatCrit is poised to give birth to the second generation of critical analysis.

A study of how the design of a tax system affects economic wellbeing is central to this analysis, particularly in the United States, where so much of our social and economic policy is effectuated through the tax system rather than through direct expenditure programs. Although tax systems operate less directly than civil rights systems in determining the well-being of an individual or group, an individual or group which is taxed disproportionately suffers an injury that is not unlike the injury suffered by an individual or group denied access to employment. Indeed, because tax systems often act invisibly, they may be even more dangerous than systems that act overtly and thus invite more immediate scrutiny and resistance. In sum, tax should count in the critical enterprise.

Tax counts for at least three reasons. First, tax policy cuts to the heart of issues of distributional equity, issues which are of acute importance to our constituent communities. Second, our cultural heritage and our perspective as critical scholars can offer a different vantage point from which to analyze the structure and operation of the tax system. Third, our presence and our influence should be felt everywhere, so all fields should be our province and no field should be off-limits. I will discuss each of these reasons in turn.

\section{Distributional EQUiTY}

Tax systems are the primary means by which democratic governments redistribute wealth. It is neither an accident nor a coincidence that some of the most respected legal philosophers of our time use the tax system as a vehicle for developing and articulating views about justice. For example, John Rawls devotes a considerable portion of his A THEORY OF JUSTICE to an analysis of the optimal tax system, ${ }^{9}$ and Robert

7. Matthew C. R. Craven, The International Covenant on Economic, Social, and Cultural RightS: A PERSPECTIVE ON ITS DEVElopMENT 8 (1995).

8. The International Covenant on Economic, Social, and Cultural Rights ("ICESCR") was adopted by the United Nations in 1966 and entered into force in 1976. Id. at 22. Article 9 of the ICESCR provides for the right to social security and Article 11 provides for the right to an adequate standard of living. Id. at 23. See also Berta Esperanza Hernandez-Truyol, Intemational Law, Human Rights, and LatCrit Theory: Civil and Political Rights-An Introduction, 28 U. MIAMI INTER-AM. L. REV. 223 (1997). For an excellent discussion of both the definition and importance of individual well-being and its connection to the prosperity of nations, see THE QUALITY OF LIFE (Martha Nussbaum \& Amartya Sen eds., 1993).

9. JOHN RAWLS, A THEORY OF JUSTICE (1971). Although Rawls discusses taxation specifically as part of his discussion of the "distribution branch," id. at 277-282, all of Chapter V, which addresses the question of distributive shares, implicates issues that are fundamental to the design of a tax system. 
Nozick uses tax systems as metaphors for society in ANARCHY, STATE AND UTOPIA. ${ }^{10}$

That tax is at the heart of inquiries about the meaning of justice is not surprising. In developing a tax system, a society must work out the relationship between the private and the public. A society must ask itself how much each individual is going to be asked to contribute to the common good, and in working out the answer to that question it must grapple with fundamental values. It should come as no surprise, then, that tax systems reflect the values of the societies that create them. ${ }^{1}$ When a colleague opens his Jurisprudence course by asking: "What is the difference between a mugger and the IRS?" he goes to the core of the connection between tax systems and justice. It is telling that in attempting to answer that question students are able to touch on most of the major themes in legal philosophy. ${ }^{12}$

\section{A. A Lesson from Cuba}

A story, both true and recent, will help to illustrate not only why I think all of us should care about taxes but also why it is that I, a Cuban refugee, do. While visiting Cuban friends in Miami, I was asked where I had boarded my Philadelphia dog. I explained that the vet had recommended a new place, ingeniously designated a "pet resort," and I recounted the experience of registering my dog there. As I explained, I had been asked how many times I wanted the "play technician" to visit my dog - for an additional fee, which would vary with the number of play sessions I ordered, a play technician would amuse my dog. As I suspect I was intended to, I ordered more play sessions than was fiscally prudent because I felt guilty about leaving my dog at the kennel. As I told this story in Miami one of my listeners shook his head and said: "Sometimes I think that what this country needs is a good dose of Fidel Castro."

Although I knew that the observation was not an endorsement of Fidel's economic philosophy, I nevertheless found the observation startling. The speaker had used Fidel to express what I consider to be a laudatory sentiment $-\mathrm{a}$ condemnation of the conspicuous consumption so prevalent in contemporary American society-but in my circle of $\mathrm{Cu}$ -

10. ROBERT NOZICK, ANARCHY, STATE, AND UTOPIA (1974). Nozick speaks of taxation directly when he compares taxation of income from labor to forced labor, id. at 169-172, and when he speaks of the differences between compulsory versus voluntary contributions to the common good, $i d$. at $265-68$, but all of the nearly 100 pages of Chapter 7, Distributive Justice, implicate the very issues that are at the heart of debates on tax policy. It is no wonder that, like many debates on tax policy, Nozick's pages contain quantitative formulations of the concepts he examines. See, e.g., id. at 210-11.

11. See Alice G. Abreu, Taxes, Power, and Personal Autonomy, 33 SAN Diego L. Rev. 1, 6469 (1996).

12. I am indebted to my colleague, Professor Richard Greenstein, who generously allowed me to take his Jurisprudence course several years ago, which he indeed began as I have described. 
ban refugee friends and relatives, I had never before heard Fidel's name used to express anything other than contempt, derision and hatred. The statement got my attention.

As I considered the differences between Fidel's reaction to the problems of income inequality and wanton consumption among Cuba's upper class during the 1950's and the reaction of American tax scholars to rampant consumerism in American society, I was struck by both the differences and the parallels. The gulf that separated the haves and the have-nots in the Cuba of the 1950's was probably no bigger than that which separates those in the top and bottom of the income distribution in twenty-first century America. The great sugar plantation owners and rum and tobacco scions of the old Cuba were easily as disparate from the campesinos who worked in the fields as the Wall Street barons, corporate executives and dot.com wunderkinds of today are from the inner-city project residents and single welfare mothers who seem to be an intractable part of urban life in the United States today. Absence of inequality does not distinguish one place from the other.

Nevertheless, the two places differ dramatically in the governmental response to inequality and its consumerist manifestations. Castro's answer was to nationalize industries and strip property owners of their holdings without compensation, while jailing or executing all who disagreed with his tactics or ideas. ${ }^{13}$ By contrast, in the United States consumerism and the paucity of individual savings have become fodder for a national debate. That debate has focused not on outlawing private property or market transactions, but on using the tax system to even the playing field and provide a disincentive for engaging in wanton consumption. Thus, the Cornell economist Robert Frank has written an entire book on the runaway train of conspicuous consumption and has advocated the use of the tax system to slow it down, ${ }^{14}$ and the pages of law journals are filled with debate over the merits of a consumption tax. ${ }^{15}$

13. For an excellent and exhaustively researched account of Cuba's social and economic situation, both before and after Castro's revolution, and a detailed analysis of its record on human rights, see Berta Esperanza Hernandez Truyol, Out in Left Field: Cuba's Post-Cold War Strikeout, 18 FORDHAM INT'L L.J. 15 (1994). Recent events have not shown a large improvement in Cuba's human rights record, as Cuba was condemned in 1999 for human rights violations by the United States Congress, by Amnesty International, and by the United Nations Commission on Human Rights. Frank Davies, House Resolution Condemns Cuba for Human Rights Abuse, MIAMI HERALD, March 24, 1999, at 17; Congress Condemns Cuba Human Rights, at http://www.cubanet.org/CNews/y99/mar99/26e8.htm; Cuba. Current Prisoners of Conscience Must be Released, at http://www.cubanet.org/CNews/y99/dec99/06e21 htm; Ariel Tapia, Inter-American

Press Society, Others Criticize New Human Rights Law, at http://www.cubafreepress.org/art/cubap990224f.html.

14. See RobERT H. Frank, LuXURY FEVER: Why MONEY Falls to SATISFY IN AN ERA OF EXCESS (1999). Frank's extensive bibliography is a further testament to the degree of attention the subject has received.

15. See, e.g., Joseph Bankman \& Barbara H. Fried, Winners and Losers in the Shift to a Consumption Tax, 86 Geo. L.J. 539 (1998); John K. McNulty, Flat Tax, Consumption Tax, 
Scholarly literature debating the merits of progressive taxation also abounds. $^{16}$

As I reflected on my Cuban friend's backhanded compliment to Fidel Castro's policy objectives, I also realized that the observation provided a window into what attracts me to the study of tax policy. For me, tax policy is interesting and important because it reflects and implements our values. Tax policy determines the distribution of the tax burden, and that affects the distribution of income and, ultimately, the distribution of wealth. However, unlike Fidel Castro's policies, tax policy in this country functions through the democratic process flawed and imperfect though it is, and respects human rights.

The beauty of tax is that a tax system that develops through the exercise of the democratic process can serve the redistributive objectives of leaders like Fidel Castro, who captivated the American left because of his egalitarian rhetoric, but can do so without obliterating civil and political rights. Tax policy allows us to distinguish between the redistributive goals of Fidel Castro, many of which were commendable, and his means for achieving them, which were almost universally reprehensible. Of course, a tax system cannot carry the weight of all of a government's policies, and how the government spends the money it collects is crucially important to the well-being of its citizens. My point is not that tax systems are everything, but only that they are an important component of social policy, one that too often is relegated to outsider status in critical discourse.

The brief exchange that began with a query about my dog allowed me to come to a more nuanced understanding of both Fidel and his revolucion on the one hand, and the near-canonization of him so prevalent within the American left on the other. For me, commendable ends do not justify repressive means, and Fidel is guilty of having sacrificed the means to the end. ${ }^{17}$ By contrast, tax systems offer the promise of achieving egalitarian ends through democratic means.

Consumption-Type Income Tax Proposals in the United States: A Tax Policy Discussion of Fundamental Tax Reform, 88 Cal. L. Rev. 2095 (2000).

16. For a sampling of recent scholarship debating the merits of progressive taxation, see, e.g., Donna M. Byrne, Locke, Property, and Progressive Taxes, 78 NeB. L. REV. 700 (1999); Donna M. Byrne, Progressive Taxation Revisited, 37 ARIz. L. REV. 739 (1995); McMahon \& Abreu, supra note 4; Jeffrey A. Schoenblum, Tax Faimess or Unfairness? A Consideration of the Philosophical Bases for Unequal Taxation of Individuals, 12 AM. J. TAX POL'Y 221 (1995); Lawrence Zelenak \& Kemper Moreland, Can the Graduated Income Tax Survive Optimal Tax Analysis? 53 TAX L. REV. 51 (1999). One of the classic treatments of the subject is WALTER J. BLUM \& HARRY KALVEN, JR., The Uneasy Case for PROGRessive TaXation (1953).

17. For a succinct history of Cuba, including Castro's revolution, and an analysis of the impact of the subsequent exodus of Cubans on U.S. immigration law and policy, see Joyce A. Hughes, Flight From Cuba, 36 CAL. W. L. REV. 39 (1999). 


\section{B. The Promise of Tax Systems}

A tax system that results from the exercise of the democratic process offers the promise of justice in both the means and the ends. A study of tax systems ought therefore to be the province of any progressive enterprise. By studying tax systems, we can learn about the connection between the operation of the system and the distribution of income. We can also discover how the design of a given tax system reflects the allocation of power, and its converse, subordination, in the society to which it applies.

Two examples will illustrate what I mean. The first will show the importance of studying the structure of the tax system and how it allocates power. The second will show the importance of studying the distribution of the tax burden in tandem with the distribution of income.

\section{The Allocation Of POWER In TaX System Design}

As I have observed elsewhere, tax systems can give, even as they are taking away. ${ }^{18}$ What tax systems can give is power. Although this is an unusual claim to make about tax systems, it is nevertheless one which is not only supportable, but which allows a more complete analysis of the way the design of a tax system affects the well-being of those on whom it is imposed. Although tax systems are usually seen as instruments of burden, not benefit, analyzing the ways in which a tax system empowers is crucial to understanding how tax systems can serve as instruments of both subordination and liberation.

\section{A. The Importance of Looking at Empowerment}

Taxes, like the coins in which they are ultimately paid, have two sides. On one side is the burden they impose. That side is easy to see and is shared by all tax systems, but the other side of tax systems is harder to see. On that other side is the empowerment that tax systems can provide. As I will explain more fully below, tax systems empower when they are designed in ways that allow individuals either to control the amount of tax they pay by behaving in particular ways or to shift the economic burden of the tax to someone else. Because not all tax systems empower and because the extent to which a tax system empowers reflects and implements important values, it is appropriate to analyze the ways in which particular tax systems empower and to examine whom they empower.

18. Abreu, supra note 11. I take much of what follows directly from that piece, although I have omitted most of the footnotes and almost all of the detailed analysis, and generally adapted the discussion for an audience of non-tax specialists. 


\section{The Ways in Which Tax Systems Empower}

Tax systems can empower individuals in at least two ways. First, they can give individuals the power to alter the amount of their tax liability by altering their behavior. For example, a tax system that provides a deduction for home mortgage interest but not for rent gives taxpayers the ability to alter (reduce) their tax liability by buying a house which they finance with a loan secured by a mortgage. ${ }^{19}$ By encouraging taxpayers to behave in ways that affect the size of their tax bills, the tax system empowers them. A taxpayer who can say to herself, "I've bought a house and now my taxes will be lower," feels in control of her tax destiny because she has taken an affirmative action that affects her tax liability. Of course, the taxpayer who cannot afford the down payment on a house and must continue to rent will not enjoy that feeling of mastery, but more about that later. The point is not that the tax system empowers everyone, but that in providing for different tax consequences for different behavior, it empowers some people.

Empowerment is not a necessary attribute of a tax system. Tax systems do not have to be designed in a way that empowers anyone. Consider, for example, a head tax. Such a tax offers few avenues for the exercise of taxpayer choice in affecting the amount of the tax burden. Outside of committing fraud, the only things that a taxpayer can do to affect the size of her tax liability under such a system are to emigrate or to die, neither of which are likely to be attractive options for most people. Consider, less drastically, a system that provides only a "standard" deduction of the same size available to everyone. Taxpayer behavior would not affect tax liability under such a system and taxpayers would therefore lack the power that the current system gives some of them. Thus, when we adopt a tax system that empowers, we are faced with deciding whom to empower.

Second, tax systems can be designed to give individuals the power to shift the economic burden of the tax. For example, a system that taxes the sale of an item gives the seller, who has the obligation to remit the amount of the tax, the ability to shift the economic burden of the tax to the buyer. The seller can effect such a shift by charging a given amount for the item and having the tax apply to that. In effect, the seller is simply collecting the tax, and it is the consumer who is bearing the economic burden of it. The design of the tax-a tax on sales-gives the seller the power to shift the economic burden of the tax to the consumer. The state sales tax systems provide ready examples of such taxes, as do the federal excise taxes, such as the federal excise tax on gasoline. Choosing a different method of taxation would change this allocation of power.

19. See I.R.C. $\$ 163($ h) (2000). This section provides for such a deduction, subject to certain limitations. 


\section{Why We Should Care About Empowerment}

Analyzing the effects of power can turn popular wisdom on its head and ensure that activists do not fall prey to the seemingly populist claims of politicians. For example, if tuition tax credits make it easier for educational institutions to raise tuition, they help educational institutions, not students and their parents. Under a similar analysis, the much-vaunted home mortgage interest deduction can change from the great helper of first time home buyers into a provision that inflates home prices because sellers can ask more, knowing that buyers will be able to deduct part of the cost. Seen this way, the deduction ultimately helps sellers and lenders, not buyers. Similarly, reducing the federal gasoline excise tax will help only gasoline sellers, not consumers, if the sellers enjoy sufficient market power to allow them to refrain from reducing the price of gasoline despite the reduction in the tax.

These effects can occur because the design of the tax system gives some people the power to affect the amount of their tax liability by changing their behavior and the power to shift the economic burden of the tax or, conversely, the power to retain the economic benefit of a tax reduction. While it is probably impossible to quantify precisely the extent to which taxes affect behavior and burdens are shifted to others, and while it is virtually certain that taxes are not the only determinant of either prices or behavior, activists and policy analysts should nevertheless be aware of the consequences of empowerment.

Indeed, analyzing the ways in which tax systems empower may be even more important than analyzing the burdens they impose. There are three additional reasons for this. First, empowerment can affect progressivity, generally by reducing it. Traditionally, the negative aspects of a tax system-its distribution of burdens-have determined its progressivity. Yet, empowerment, which is generally positive, can offset the negative aspect of the burden. Empowerment can therefore reduce the net burden imposed by a tax system, and, by doing so, reduce its overall progressivity. To analyze the distributive impact of a tax system in its entirety, activists and policy analysts should ask not only how much the system takes away and from whom (the burden) but should also ask how much it gives and to whom (the empowerment). Only then can a complete picture emerge.

Second, empowerment can affect the visibility, and consequently the accountability, of a tax system. When a system places its burden on someone who has the power to shift that burden, it effectively taxes people who will often not know that they are being taxed. Taxation that is invisible is even worse than taxation without representation. One cannot rebel against, much less attempt to change or reform, that which one does not know is there. 
Third but perhaps of greatest importance, a tax system that empowers people to shift the economic burden of the tax vests in private individuals the authority to decide how the burden of a tax shall be allocated. In a tax system where the nominal burden of paying the tax coincides with the economic burden, where no shift is possible or likely, the government decides who pays and how much they pay. By contrast, in a tax system that permits the shifting of the economic burden, the nominal bearer of the tax decides who will bear the economic burden. Under such a system, taxation proceeds, at least proximately, from the nominal bearer's exercise of her power to shift the economic burden of the tax. Such a system has great potential for treating similarly situated individuals differently.

\section{B. Application to the Current Federal Tax System}

A review of the current federal income tax system reveals that the system grants many choices, but it generally grants those choices to people who possess material wealth. It therefore distributes choices progressively, just as it distributes burdens. A comparison of the way the two most significant federal tax systems, the federal income tax and the federal employment (social security) tax system, allocate choices will illustrate the ways in which the allocation of power in tax system design implicates values.

Under the income tax system, the wealthier an individual is, the greater the number of choices she has. Not only do those with less wealth have fewer choices under that system, they also have a greater proportion of their wealth subject to tax under the other system, one that provides virtually no opportunity for the exercise of taxpayer choice-the social security tax system. Indeed, studies have shown that "lower- and middleincome Americans now pay more social [security] taxes than they pay in federal income taxes."

By contrast to the federal income tax system, the social security tax system provides little opportunity for the exercise of choice. The mere receipt of compensation for personal services generates the liability for the tax. No deductions and very few exclusions exist regardless of what the taxpayer does. For most taxpayers, the only choice the system provides is not to work. ${ }^{21}$ Why is it that the tax that imposes the greatest burden on low- and middle-income Americans is also the tax with the small-

20. Chris R. Edwards, Typical American Family Pays 40 Percent of Income in Taxes, 66 TAX NOTES 735, 735 (1995).

21. There are some types of work that will not generate liability for the social security tax, such as work by a minister of a church, I.R.C. $\$ 3121$ (b)(8)(A) (2000), and work by newspaper delivery people under 18 years of age, I.R.C. $\S 3121$ (b)(14)(A) (2000), but they are generally of fairly narrow application. I.R.C. $\$ 3121$ (b) (2000). 
est opportunity for the exercise of choice? It is because of the value we, as a society, place on material capital.

Taken as a whole, the federal tax system provides for the exercise of choice in proportion to wealth. This exercise of choice turns a seemingly progressive system, like the income tax system, into one in which the outward appearance of progressivity can be overturned "by the voluntary actions of individual persons over time" and in which the connectedness wrought by the objective of progressivity is undercut by the disconnected manner in which each choice is exercised. ${ }^{22}$ Moreover, because bestowing the power to choose in proportion to wealth is itself anti-egalitarian, possession of the power can overturn the egalitarian objective even if that power is not used. ${ }^{23}$ The rich can buy houses, invest in taxadvantaged financial instruments, and get paid in stock options that generate no current income or employment tax liability, but the working poor have none of those choices. ${ }^{24}$ By distributing the power to choose in proportion to wealth, the federal tax system contributes to the subordination of poor people, particularly poor working people.

As the data discussed in the next part will illustrate, under the current tax system the rich win the choice sweepstakes, as well as the tax distribution sweepstakes. Although wealthy individuals pay a higher proportion of their income in taxes than poor individuals, the data reveal that over a 10 -year period, the increase in the income of the wealthiest $1 \%$ of the population has far outpaced the increase in their tax burden.

\section{THE DistRIBUtion OF INCOME AND the DisTRIBUTION OF THE TAX BURDEN}

It is no longer news to point out that the distribution of income in this country is very unequal and that income inequality is increasing at an alarming rate. Indeed, Enrique Carrasco, a prominent LatCrit scholar, extensively and persuasively documented this phenomenon. ${ }^{25}$ What is much less well known is the role of the tax system in perpetuating and exacerbating the unequal distribution of income. Although many of us may not be surprised to find out that most of the gains in income have gone to those at the very top of the income distribution, we might be

22. NozicK, supra note 10 , at 164 ("Any distributional pattern with any egalitarian component is overtumable by the voluntary actions of individual persons over time.")

23. See id.

24. The eamed income tax credit, which was intended to provide some relief for the working poor, is, at best, a blunt instrument, and at worst, largely ineffective. See Anne L. Alstott, The Earned Income Tax Credit and the Limitations of Tax-Based Welfare Reform, 108 HARV. L. REV. 533 (1995); and George K. Yin et. al., Improving the Delivery of Benefits to the Working Poor: Proposals to Reform the Earned Income Tax Credit Program, 11 AM. J. TAX PoL'Y 225 (1994).

25. Enrique R. Carrasco, Opposition, Justice. Structuralism and Particularity: Intersections Between Latcrit Theory and Law and Development Studies, 28 U. MIAMI INTER-AM. L. REV. 313 (1997). 
surprised to compare the changes in the distribution of income with the changes in the distribution of the tax burden. ${ }^{26} \mathrm{We}$ are fast becoming a winner-take-all society, and the winners are winning the income sweepstakes, the choice sweepstakes, and the tax sweepstakes as well. ${ }^{27}$

First, let us look at what has happened to the distribution of income. "In 1990, families in the top $20 \%$ of the income scale received $51.4 \%$ of all income; families in the top [one percent] received nearly $13 \%$ of all income [but] families in the bottom [forty percent] also received $13 \%$ of all income. ${ }^{, 28}$ Something is wrong when families in the top [one percent $]$ of the income distribution receive as large a share of total income as families in the bottom [forty percent]. Figures 1 and 2, below, paint the picture.

26. This discussion is taken from McMahon \& Abreu, supra note 4, at 7-8, although I have omitted many of the footnotes given the difference in the audience for which the discussion is intended. Those interested in the more complete treatment of the subject are invited to read the full article.

27. See Robert H. Frank \& Philip J. CoOK, ThE WinNer-TAKe-All-Society (1995).

In The Winner-Take-All Society, Frank and Cook describe how an increasing number of labor markets now operate in ways that depart significantly from the classical economically efficient model. In these markets, a large number of individuals compete for a relatively small number of positions that offer the possibility for financial rewards far exceeding those that await less successful competitors. As in the entertainment industry, where the difference between the compensation received by the star and that received by her understudy is almost always far more than proportional to the differences in their talent, these steadily growing markets display what is essentially a winner-take-all paradigm.

McMahon \& Abreu, supra note 4, at 3-5.

28. McMahon \& Abreu, supra note 4 , at 5. 


\section{FIGURE $1^{29}$}

Shares of Pre-Tax Income for All Families in 1990

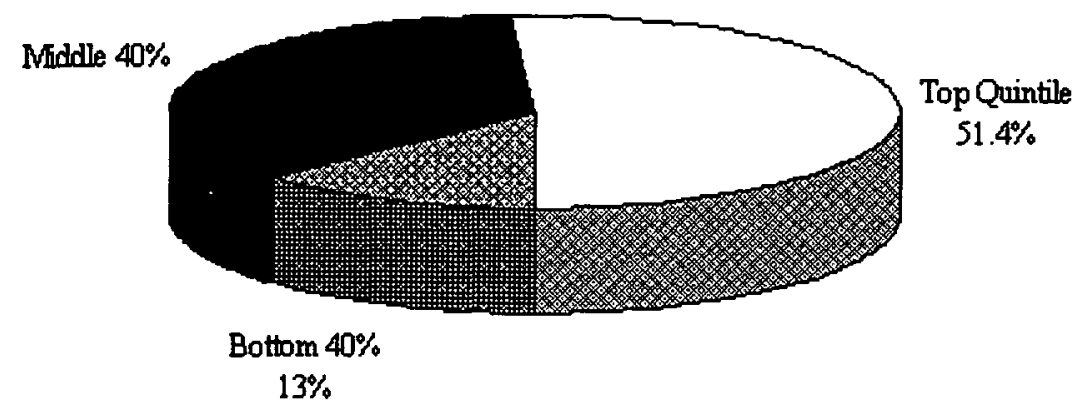

\section{FIGURE $2^{30}$}

Share of Pre-Tax Income in 1990 for Families in the Top Quintile

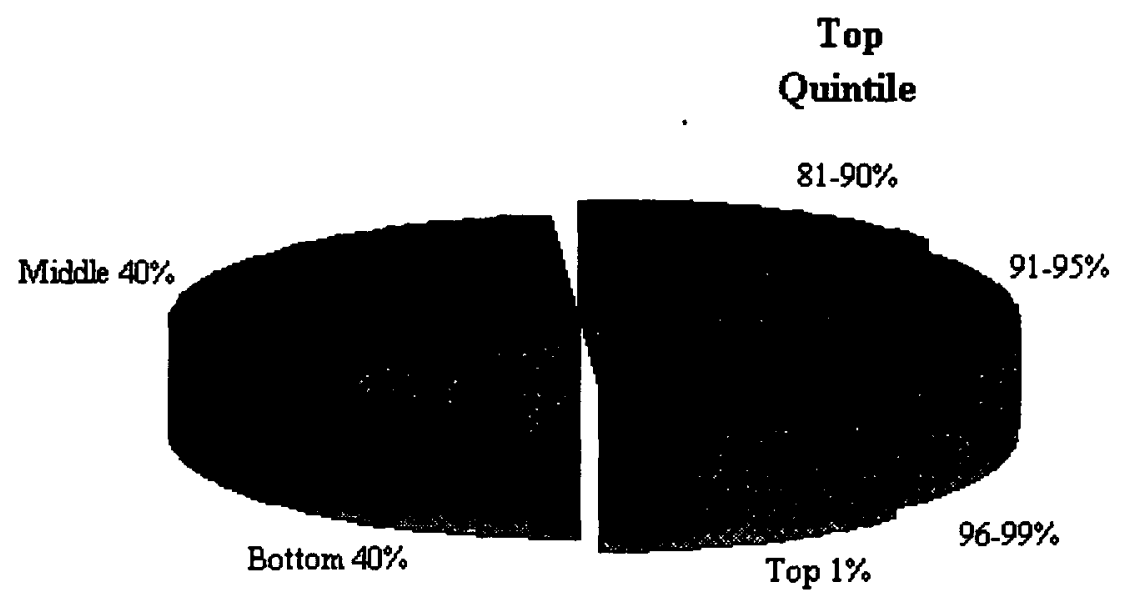

29. Id. at 6 .

30. Id. at 7 . 
Not only was the distribution of income skewed dramatically towards the top of the income scale a decade ago, but more importantly, the increases in income went disproportionately to those at the top of the distribution. While most American families were seeing their share of total income decline, and families at the bottom of the income distribution were seeing their share decline by nearly $25 \%$, families in the top one percent increased their share of income increase by an extraordinary forty-five percent. ${ }^{31}$

This would not be troubling if the distribution of the federal tax burden had kept pace with the distribution of income, but that is one race the winners have been losing. As Professor McMahon and I noted in Winner, "while changes in shares of income and taxes have remained in rough proportion to one another for $99 \%$ of the population, the increase in share of income has outstripped the increase in share of taxes by a factor of almost 5 for those at the top $1 \%$ of the income scale-the real winners. The spike in the graph confirms both the expansion of winner-take-all markets and the growing disjuncture between the distribution of income and the distribution of the tax burden." ${ }^{32}$ While the share of income received by families in the top $1 \%$ rose by $45 \%$ during that period, their share of the tax burden only rose by $9.5 \% .{ }^{33}$ Figure 3 , below, paints this picture.

31. Id.

32. Id. at 8 .

33. Id. at 9 . 


FIGURE $3^{34}$
Changes in Shares of Income and Taxes 1977-
1990

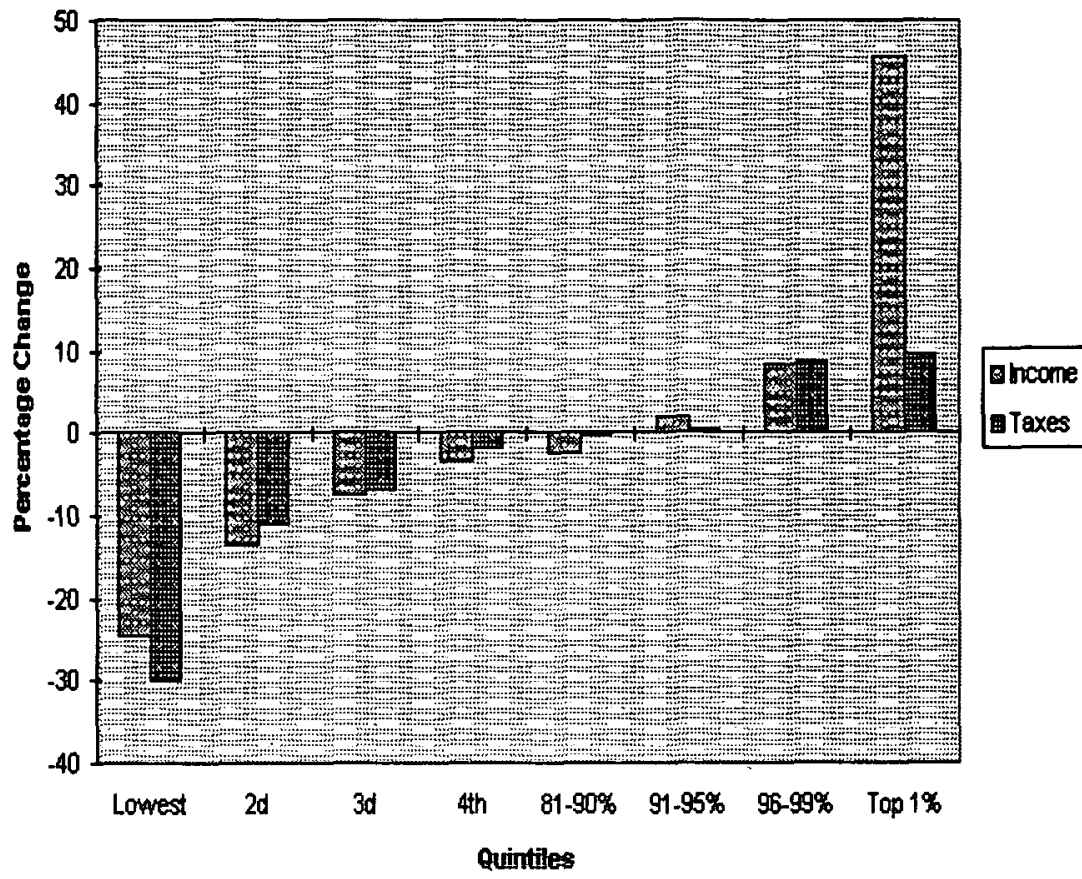

Neither activists nor tax policy scholars have considered the ways in which the distribution of income within the top quintile should affect the distribution of the tax burden. While the data on which Figure 3 is based confirms the widely touted claim that individuals at the top of the income scale pay more than half of the taxes (according to the forgoing data, families in the top quintile paid more than $51.5 \%$ of the taxes in 1990), that assertion overlooks the relationship between their share of income and their share of taxes. Not only did the share of income held by individuals in the top $1 \%$ go up almost five times faster than their share of the tax burden, but they were the only income category which enjoyed such disparity between the increase in their income and the increase in their tax liability. Individuals in almost all other income categories witnessed a reduction in their share of taxes that was commensurate with the reduction in their share of income or that was actually smaller than the reduction in their share of income. Only the individuals in the lowest quintile saw a reduction in their share of the tax burden that was greater

34. Id. 
than the reduction in their share of income, but the size of the reduction in their share of income was so great that the slightly greater reduction in their share of the tax burden must have been small comfort.

Given the structure of the federal income tax system and they way in which it distributes power, as described supra, the forgoing result is not surprising. What is surprising is that tax issues have only recently begun to come within the purview of critical scholars. By participating in LatCrit, I hope that I can contribute to changing that.

\section{TAX FOR EVERYONE}

Critical scholars have begun to apply the tools of critical analysis to the current tax system and in so doing have provided us with much food for thought. Thus, Dorothy Brown has studied whether the marriage penalty affects black couples disproportionately, concluding that it does, ${ }^{35}$ Beverly Moran and William Whitford have looked at the Internal Revenue Code from a critical race theory perspective, ${ }^{36}$ and David Brennen has considered what would happen if the Treasury were to take the position that race-based affirmative action policies violate social policy and hence revoke the tax exemption enjoyed by educational and other charitable institutions. ${ }^{37}$ Other examples abound: feminist scholars have also provided insightful critiques of the current tax structure, ${ }^{38}$ scholars working in queer theory have begun to analyze the heterosexual bias in the Code ${ }^{39}$ and an entire book was devoted to essays written by critical tax scholars on a variety of topics. ${ }^{40}$ But those efforts have met with substantial resistance from within the tax academic community, and much

35. See, e.g., Dorothy A. Brown, The Marriage Bonus/Penalty in Black and White, in TAXING AMERICA 45, 45-57 (Karen B. Brown \& Mary Louise Fellows eds., 1996); Dorothy A. Brown, Race, Class, and Gender Essentialism in Tax Literature: The Joint Return, 54 WASH. \& LEE L. REV. 1469. 1501 (1997); Dorothy A. Brown, Split Personalities: Tax Law and Critical Race Theory, 19 W. NEW ENG. L. REV. 89, 92 (1997).

36. See Beverly I. Moran \& William Whitford, A Black Critique of the Internal Revenue Code, 1996 WIS. L. REV. 751.

37. See David A. Brennen, The Power of the Treasury: Racial Discrimination, Public Policy, and "Charity" in Contemporary Society, 33 U.C. DAvis L. REV. 389, 392-93 (2000).

38. Happily, there are many articles on tax written from a feminist perspective, and I am not even going to attempt to provide a bibliography. Nevertheless, for a recent, and very far from comprehensive, sampling, see Anne L. Alstott, Tax Policy and Feminism: Competing Goals and Institutional Choices, 66 ColuM. L. REv. 2001 (1996); Wendy C. Gerzog, Solutions to the Sexist QTIP Provisions. 35 REAL. PROP. PROB. \& TR. J. 97 (2000); Marjorie E. Kornhauser, What do Women Want: Feminism and the Progressive Income Tax, 47 AM. U. L. REV. 151 (1997); Nancy C. Staudt, Taxing Housework, 84 GEO. L.J. 1571 (1996).

39. See, e.g., Patricia A. Cain, Heterosexual Privilege and the Internal Revenue Code, 34 U.S.F. L. REV. 465 (2000); Nancy J. Knauer, Heteronormativity and Federal Tax Policy, 101 W. VA. L. REv. 129, 132-133 (1998); and Patricia A. Cain, Taxing Lesbians, 6 S. CAL. REv. L. \& WOMEN'S STUD. 471, 472 (1997).

40. See TAXING America (Karen B. Brown \& Mary Louise Fellows eds., 1996). 
work remains to be done. ${ }^{41}$ Word of that work needs to spread beyond the ranks of tax scholars.

Latina/o scholars have much to contribute to this critical enterprise. Not only do we have a perspective traditionally underrepresented in tax policy debates, but the diversity in our community cannot help but enrich those debates. For example, Alfonso Morales has advanced our understanding of tax compliance behavior based on his field study of recent immigrants from Mexico, which demonstrated the complexity of tax compliance decisions and the influence of what Morales terms "supplyside" considerations in tax avoidance behavior. ${ }^{42}$ Following are other examples of the ways in which a Latina/o perspective can affect tax policy debates. I confess that my thinking in this area is embryonic, but I offer it because it has the potential to prompt others to add their voices and thus enrich the discourse, and to underscore the importance of tax to the LatCrit enterprise.

\section{A. Citizenship}

For some portions of our community, citizenship matters, and citizenship matters a lot in some areas of taxation. My own interest in the taxation of individuals who renounce U.S. citizenship to save taxes-taxmotivated expatriation, as it has come to be known-grew out of the very personal way in which I value my U.S. citizenship. That personal connection caused me to think about it often and led to interesting discussions whenever I taught the subject in my course on International Tax. It is not surprising that when Congress proposed significant changes in this area, writing about it was easy ${ }^{43}$ I do not think that it is mere coincidence that I was the first scholar to publish a law review article on the subject, and I wonder whether it is mere coincidence that the second such article by an academic was also written by a Cuban. ${ }^{44}$ That we take differing positions is further evidence of the diverse ways in which Latina/os can enrich the debate, even in what seems like a technical area of the law.

41. See, e.g., Lawrence Zelenak, Taking Critical Tax Theory Seriously, 76 N.C. L. REv. 1521, 1522-23 (1998). Much of that issue of the North Carolina Law Review was devoted to the issue of ritical tax and contained both scathing critiques of the enterprise and powerful defenses. The work of critical tax scholars was, however, featured in the most recent AALS-sponsored Workshop on Taxation held in Washington D.C. in October, 1998.

42. See Alfonso Morales, Income Tax Compliance and Alternative Views of Ethics and Human Nature, in THE ETHICs Of TAX EVAsion 242, 252-57 (Robert W. McGee ed., 1998).

43. See Alice G. Abreu, Taxing Exits, 29 U.C. DAvIS L. REV. 1087, 1087-89 (1996).

44. See Jeffrey M. Colon, Changing U.S. Tax Jurisdiction: Expatriates, Immigrants, and the Need for a Coherent Tax Policy, 34 SAN DIEgo L. REV. 1 (1997); Renee S. Liu, Note, The Exparriate Exclusion Clause: An Inappropriate Response to Relinquishing Citizenship for Tax Avoidance Purposes, 12 GEO. IMMIGR. L.J. 689 (1998). 


\section{B. Residence}

My connection to my citizenship has also made me interested in the ways in which the tax system discriminates against individuals who have resident status for tax purposes (and are therefore subject to the full force of U.S. taxing jurisdiction even though they cannot vote and often do not enjoy resident status for immigration purposes), and who are sometimes treated more harshly than citizens. Although my work in this area has barely begun and its fruits will have implications far beyond the Latina/o community, my interest in undertaking it is undoubtedly colored by my family's experience, for a time, as tax-paying but non-voting U.S. residents.

\section{Culture}

My perspective as a Latina and my understanding of Latina/o culture has also been useful in helping to understand the administration of the tax laws. During a discussion of the Internal Revenue Service's treatment of immigrants who claim the Earned Income Tax Credit at an ABA Tax Section meeting several years ago, I was struck by the way in which cultural assumptions informed, or, more accurately, misinformed, the Service's interpretation of actions by members of some immigrant groups. The discussion centered on the problem of grandparents, aunts, and uncles who claimed that certain children were their dependents even though the adults' relationship to the children did not fit the definition of dependent established for that purpose in the Code. The underlying assumption seemed to be that the individuals in question were either stupid or dishonest. To me, however, an alternative explanation for the difficulty was at least plausible: a difference in the cultural assumptions about who was "family."

In Latino culture, extended families are common and the bonds between generations are often strong. It is not uncommon for multiple generations to share a dwelling, which makes it harder to sort the familial relationships into the more atomistic and money-based categories of Anglo culture, which the Code reflects. Such a difference in cultural perspective could explain the behavior the Service was seeing and could allow for more thoughtful responses to the communication problem it posed. My participation in that discussion did not lead to a new legislative initiative and was less than a drop in the bucket of solutions to administrative problems in the tax system. I was speaking to but a handful of individuals who are part of a system that consists of thousands. Nevertheless, what I was able to do in the context of that handful of individuals illustrates the changes that can occur as more of us who can bring a different cultural perspective develop the technical expertise and the clout to move in those circles. 
I could not have made a difference in that context had I not first mastered the technical aspects of the tax law. But I was able to offer something beyond technical mastery: a different cultural perspective that technical mastery alone cannot supply. Others can make similar contributions, and every little bit will help.

\section{CONCLUSION}

The paucity of current work on the impact of the tax system on the Latina/o community leads me to conclude by again urging that more of us need to become engaged in this work. We need more Latina/o tax teachers who can not only serve as role models, but who can also eloquently state, by their presence, that this is a field open to all. As a community, we also have to be willing to embrace tax and other business subjects so that our students do not feel they have to suppress any interest or passion they may have for them. We have to nurture our students' interest in these subjects by making the subjects ours.

Nurturing more minority tax lawyers is crucial to the critical enterprise for another reason. Even if the study of tax systems could not offer insights important to the LatCrit anti-subordination project and even if the experience of Latina/os could not enhance tax policy discourse, it would be important for Latina/os to become tax lawyers. By being at the table, I believe that I help to earn respect for Latinas and Latinos. By being a walking billboard for the intellectual diversity of Latinas and Latinos, I think I advance the cause of inclusion and empowerment generally.

If we are to make a difference, if we are to achieve for ourselves the kind of self-actualization to which I think we all aspire, our presence must be felt in every facet of life. For those of us who are lawyers, that means in every facet of law, including the money-law areas traditionally closed to us and often alien to our lives. In other words, tax counts, and all of money-law should become a vibrant part of the critical enterprise. Tax should not be just for tax people anymore. 
